\title{
Returning to Solvency Through Quality Improvement
}

Matthew Faciane, DBA

Saint Leo University, St. Leo, Florida, United States

Susan K. Fan, DM

Walden University, Minneapolis, Minnesota, United States

Rocky J. Dwyer, PhD

Walden University, Minneapolis, Minnesota, United States

(iD https://orcid.org/0000-0001-7929-976X

Contact: $\underline{\text { matthew.faciane@saintleo.edu }}$

\section{Abstract}

The purpose of this qualitative case study was to explore quality improvement strategies senior manufacturing production managers use to reduce Cost of Poor Quality (COPQ) to increase profit. The participants for this study were production managers within a manufacturing company located in the southeastern region of the United States who successfully developed and implemented strategies to lower COPQ to increase profitability. Six major themes emerged from the study: continuous improvement, quality assurance, employees as agents of quality improvement, communication between stakeholders, holding all firm members accountable for quality, and training. Manufacturing managers can use these strategies to lower COPQ and increase profits, which could result in enhancing other organizations' financial performance. Findings from this study may enable manufacturing managers to improve organizational performance when continuous quality improvement processes are implemented throughout the manufacturing process and senior leaders champion lessons learned, support the training program approach, and implement a quality assurance program that empowers frontline employees as agents of quality throughout the manufacturing process.

Keywords: Continuous improvement; Cost; Quality improvement; Six Sigma; Total Quality Management

Date Submitted: October 31, 2020 | Date Published: April 6, 2021

\section{Recommended Citation}

Faciane, M., Fan, S. K., \& Dwyer, R. J. (2021). Returning to solvency through quality improvement. International Journal of Applied Management and Technology, 20, 1-16. https://doi.org/10.5590/IJAMT.2021.20.1.01

\section{Background}

Costs of poor quality (COPQ) are a major business problem negatively affecting firms throughout the business community (Jaca et al., 2014; Stanciu \& Pascu, 2014). While there are potential solutions to the COPQ business problem (Ahmad et al., 2015; Deming, 1986; Kanwarpreet \& Inderpreet, 2015), COPQ can cause significant revenue losses within the manufacturing industry when business leaders fail to take remedial action (Ahmad et al., 2015; Stanciu \& Pascu, 2014; Pakdil \& Leonard, 2014). Business leaders can mitigate complications associated with COPQ by implementing quality improvement strategies aligned with a Total Quality Management (TQM) approach (Drohomertetski et al., 2014; Hunold, 2014; Parihar et al., 2015). 
When a significant level of COPQ occurs, vast amounts of financial and human capital are consumed to determine and then correct the system processes to avoid future occurrences (Pakdil \& Leonard, 2014). In addition, there is organizational reputational degradation, production waste, rework, scrapping, and safety impacts, which impact the ability of production managers to control quality, maintain continuous improvement initiatives, and ensure quality oversight (Ahmad et al., 2015).

As various researchers (Deming, 1986; Kawai, 2014; Pakdil \& Leonard, 2014) have noted, poor business performance via decreased earnings has the potential to create an adverse effect beyond the organization into the extended business community and the labor force.

\section{Problem}

In the manufacturing industry, losses stemming from poor quality, internal and external failures, rework, and scrap may range from $20 \%$ to $100 \%$ of the entire cost of products manufactured (Ahmad et al., 2015; Stanciu \& Pascu, 2015). In fact, COPQ further impedes firm performance and results in reputational degradation, waste, rework, scrapping, and workplace safety issues. Some of the causes identified with COPQ are the inability of managers to control quality, the lack of processes such as continuous improvement initiatives, and the lack of quality oversight (Ahmad et al., 2015), all of which contribute to reduced profitability. Since senior managers in the manufacturing industry experience adverse effects originating from poor quality control resulting in profit losses, this study explored the strategies manufacturing production managers used to reduce COPQ and increase profits.

\section{Purpose}

This qualitative study explored the quality improvement strategies senior manufacturing production managers used to reduce COPQ and increase profitability. The targeted population were manufacturing production managers in the southeastern region of the United States with proven expertise in successfully developing and implementing strategies to lower COPQ.

\section{Method/Design}

This study incorporated a qualitative case study approach to ensure a broad understanding of a phenomenon based on the participants' experiences. The targeted population were manufacturing production managers in the southeastern region of the United States who were purposefully selected based on the depth and breadth of their manufacturing experience and expertise in implementing quality improvement strategies to reduce production costs, which increased profitability. Data collection was conducted using interviews, a review of internal and external corporate documents, and organizational websites to ensure data saturation.

\section{Conceptual Foundation}

In conducting this study, Deming's (1986) TQM was employed to explore strategies that production managers within a manufacturing company implemented to lower COPQ to increase profitability. Patyal and Maddulety (2015) noted that when manufacturing managers seek ways to improve the quality of their products, decreasing COPQ can catalyze production processes efficiencies and effectiveness, a point also made by Sangode (2016). Furthermore, the ability of the organizational managers to reduce COPQ is dependent on their capacity to improve quality via prevention, appraisals, and improvements (Ahmad et al., 2015). The expectation was that TQM theory could provide a lens for understanding the phenomenon and how to use strategies to lower COPQ. 
Faciane et al., 2021

\section{Total Quality Management}

Deming's (1986) TQM is a holistic quality improvement concept, which organizational members use to improve quality continuously (Deming, 1986; Nawelwa et al., 2015). Creating constancy toward improving quality enables organizational leaders to provide the foundation of a good quality management system that can sustain an organization over the long term. When manufacturing leaders create constancy to improve quality, they find using the principle often fosters stakeholder collaboration toward a mutual interest of longterm sustainability wherein the group focuses on continuous improvement and innovative ideas to enhance performance (Lagrosen \& Travis, 2015). Creating constancy also helps organizational leaders set quality improvement objectives and goals to create quality improvement initiatives and subsequent employee performance (Lagrosen \& Travis, 2015). When leaders create constancy in quality management through stakeholder engagement, the enabling collaboration activity supports benchmarks and subsequent performance assessment.

Adopting the TQM philosophy is critical to success in meeting quality improvement goals. Manufacturing leaders implementing all aspects of a TQM strategy experience better production levels and financial performance than manufacturing leaders who have a lower orientation to TQM principles (Chaudary et al., 2015). Organizations with staffs who adopt and maintain buy-in to quality improvement practices consistent with TQM generally achieve a high level of quality in their products (Sunder, 2016). A significant barrier to the implementation of a quality management system is top managers' lack of adoption of the philosophy (Jaeger \& Adair, 2016). However, organizations with employees and top-level managers who fully adopt a culture of quality and incorporate all TQM principles can achieve superior product and process quality and potentially circumvent barriers to the successful implementation of the quality improvement program.

Building and designing quality into a product is the responsibility of the individuals composing the products and the quality improvement strategy; firm leaders should not count on mass inspections unless firm members produce complex products. Building quality into the product reduces the likelihood of COPQ because manufacturing managers and manufacturing workers who wait for mass inspections to find quality failures do not improve the system and the practice often causes internal quality failures requiring rework or scrapping (Deming, 1986). Building quality into products is the act wherein employees construct the product to meet the original design specifications through the standardization of work (Gupta \& Jain, 2015). Standardization aids in ensuring that the customer will receive the quality item they need (Juran, 1989). Relying on mass inspection implies quality failures will occur, which is counterproductive. Manager should instead make all workers responsible for quality and building quality into every product (Deming, 1986). Mass inspections also require significant investments and can negatively affect profits (Deming, 1986; Diamandescu, 2016; Kafetzopoulos et al., 2015). Some inspections are necessary, such as statistical analyses of quality variance and products with high levels of complexity, such as technological and communication hardware, which require thorough inspections (Deming, 1986). Building quality into products is an act employees carry out to ensure that a quality failure does not occur and customers receive a product meeting their specifications. Firm leaders relying only on mass inspections will likely have a higher rate of quality failures than companies with employees building quality into their products.

When manufacturing leaders decide to use quality suppliers, they lower the chance of differing materials and supplies, which increases the likelihood of incurring COPQ. The suppliers' product quality is the most important factor to consider when choosing a supplier (Tang \& Hsu, 2015). The material purchased from a supplier has an effect on the COPQ (Deming, 1986; Juran, 1989). Purchasing materials from suppliers with high grades in quality lowers the likelihood of internal and external failure, as the materials are of higher dexterity. In many business arrangements, materials from the supplier fit other supplies the manufacturer ordered to make up the end product and meet specifications. Ordering from differing suppliers increases the risk of a quality failure as the materials are not intended to work in tandem, which could cause a deviation 
affecting the quality of the product (Deming, 1986). Quality suppliers also efficiently manage their supply chain and will likely not have gaps wherein they cannot fulfill orders for material promptly, which can reduce delays in cycle times (Yadav \& Sharma, 2016). The practice of ordering from quality suppliers lowers the probability of internal and external quality failures.

Improving a firm's affinity to reduce process variation during manufacturing operations decreases the likelihood that members will make mistakes that cause quality failures. Production managers should design products to meet the demands of the customer and activities necessary to enable the successful composition of such products (Juran, 1988). Firm leaders should enlist the feedback of the customers to understand consumer needs and seek feedback necessary to meet their needs (Juran, 1988, 1989; Mitreva et al., 2016). Juran (1988) noted customers' needs should be weighted on their importance to the firm, as there are two categories of customers, the vital few consisting of the majority of the sales and the useful many, which positively affect firm performance but to a lower level than the vital few. Firm leaders should focus on satisfying the needs of all customers but with a higher concentration on meeting the needs of the vital few (Juran, 1988). After the management team develops processes necessary to configure the products, organizational members should strive to eschew deviation from such procedures to lower the likelihood of COPQ occurring (Patyal \& Maddulety, 2015). Firm leaders can track employees' deviations from the standardized work necessary to achieve product quality through statistical analyses (Deming, 1986). When the deviations are beyond the control limits, process improvement teams can conduct causal analyses to find causes and develop countermeasures to circumvent the problems. Using such practices improves processes and managers can check the effectiveness of the countermeasures using TQM's Plan Do Check Act (PDCA) after the countermeasure's implementation (Kanwarpreet \& Inderpreet, 2015).

Often in Western manufacturing firms, managers expect employees to integrate into their position without training. The supervisor often initiates training activities without considering learning styles, creating a problematic learning environment (Deming, 1986). Offering individualized training to employees may enhance all organizational members' performance (Mishra \& Smyth, 2015). Many manufacturing managers in the West often fail to provide adequate training. When managers give individualized training based on the individuals learning style, the training endeavors could benefit all members and the leadership of the organization.

Instituting leadership into the organization enhances quality improvement. Good leaders are critical to the success of TQM (Dubey \& Gunasekaran, 2015). Establishing leadership enables a higher affinity toward quality because leaders are subject matter experts on the work their subordinates perform. Ninety-five percent of manufacturing managers employ supervisors who have no knowledge of the production process, which could impair business leaders in attaining their quality goals (Deming, 1986). Institutionalizing leadership into an organization increases the motivation levels among employees necessary to fulfill organizational goals (Hyvari, 2014). The institutionalization of leadership enhances quality via the supervisor's experience and in overcoming barriers to quality. Leadership motivates employees to meet quality expectations. Incorporating managers without specialized experience and leadership skills may negatively affect the quality improvement program.

Leadership is necessary to enhance employees' knowledge, skills, and abilities and to improve quality. Organizational leadership is required to improve training and education within a firm (Bloice \& Burnett, 2016). Increasing the level of knowledge through training employees could increase the employees' ability to improve quality (Deming, 1986). Leaders have specialized knowledge about the work their subordinates perform (Deming, 1986; about subordinates' cultural patterns, Juran, 1989). Leaders motivate employees to perform at an optimal level (Deming, 1986; Juran, 1988). Good leaders are necessary to motivate employees and expand their breadth and depth of knowledge. Institutionalized leadership enhances organizational members' capacity to improve quality by motivating employees to fulfill the managers' quality improvement 
goals. Managers with leadership skills help to expand subordinates' knowledge bases, which has a positive effect on performance.

The elimination of interdepartmental barriers enhances the effectiveness of TQM. Barriers in manufacturing organizations hinder team members' ability to work as a cohesive team (Bloice \& Burnett, 2016). Teamwork among organizational members enhances the quality of the organizational members' products and services, and collaboration is necessary to meet requirements to meet customer demands (Jung, 2016). When corporate leaders are inclusive and incorporate all departments, they garner a deeper understanding of quality problems (Kanwarpreet \& Inderpreet, 2015). Department members can communicate and collaborate more efficiently and develop better solutions for the firm when there is a lack of barriers between the departments (Marodin \& Saurin, 2015). When employees work interdepartmentally, they can improve quality through diverse perspectives necessary for enhancing the quality of products and services.

Teamwork improves when employees focus on meeting quality goals and when leaders remove slogans, exhortations, and targets for productivity. Slogans of productivity and quality are a barrier to a quality improvement program (Bhat \& Rajashekhar, 2009). Individuals from differing departments, which have exhortations and slogans, could have adversarial relationships due in part to the contentious rhetoric (Cannon, 2002). Business leaders who exhort about achieving zero defects are unreasonable and managers should strive to lower quality-related problems without using means with the potential to cause frustration and animosity among staff members (Deming, 1986). Proclamations with the propensity to fracture the unity of effort of an organization could hinder production and quality.

The elimination of management objectives and quotas for manufacturing employees helps to develop a culture of quality (Deming, 1986). When managers direct employees to produce some products within a given amount of time, product quality may decrease as the workers aim to meet numerical goals and focus on speed rather than quality (Lawton and Ivanov, 2014). If the individual substitutes the desire to complete the composition of a certain number of products with building a product of high quality, employees could focus solely on their rewards and not the voice of the customer (Melton \& Anthony, 2015). Focusing on the voice of the customer is fundamental in meeting quality specifications (Juran, 1988). Organizational leaders are more likely to meet a higher level of product quality by focusing on motivating their employees to become quality centric instead of meeting production quotas (Deming, 1986). Firm leaders who want to improve quality should remove quotas motivating employees to work on speed rather than building quality goods (Deming, 1986; Lawton \& Ivanov, 2014).

Organizational leaders with an affinity for a culture of quality often eliminate barriers to their workers' job satisfaction leading to increased product quality (Deming, 1986). Leaders should not manage by objective and numerical quotas. Rather, they should allow employees to work in a manner that gives them pride in their craft, with a focus on the quality of products instead of the number of goods produced (Deming, 1986).

Enhancing the employees' satisfaction level causes increased productivity and the quality of their performance (Jung, 2016). When managers motivate employees to focus on quality, the practice enhances job satisfaction, quality, and has a byproduct of increased productivity, while leaders who focus on quantity instead of quality could impede the quality goals of the organizational leaders.

Manufacturing leaders can decrease COPQ by institutionalizing self-improvement and education within the firm. Quality improvement training endeavors enhance the quality of products (Patyal \& Maddulety, 2015; $\mathrm{Wu}, 2015)$. Quality centric education programs and certifications reduce quality failures via teaching employees how to identify waste, training workers how to use causal analysis to identify quality failures, informing employees about effective quality failure countermeasures, and teaching employees how to monitor the efficiency of the quality improvement program through statistical analyses (Nagi \& Altarazi, 2017). The implementation of education and training programs helps employees monitor and improve quality. 
When manufacturing managers task all members of the company with being responsible for quality, staff has more buy-in for a quality improvement program. If all employees are responsible for quality management, they all have a vested interest in the program's success (Kanwarpreet \& Inderpreet, 2015). Business leaders tasking employees with investing in the quality improvement program enhances buy-in (Diamandescu, 2016; Kanwarpreet \& Inderpreet, 2015). When all of the employees of an organization buy into a quality improvement program, there is a lower correlation with quality failures causing COPQ (Wu, 2015). Making quality a responsibility of all employees increases buy-in, which enhances the organization's quality performance.

\section{Critiques of Total Quality Management}

There are several critiques of TQM. Kafetzopoulos et al. (2015) claimed quality improvement practices might not enhance financial performance via increased profits. Researchers in the past found TQM might not improve the financial results or lower COPQ. TQM may not improve the quality, or the benefits associated with a high degree of quality.

TQM practices may not increase profits by lowering COPQ. Quality management practices may not increase profits due to the growth of quality costs due to practices firm members must take to improve or improve and control quality (Kafetzopoulos et al., 2015). Quality costs associated with inspections, validation checks, and auditing activities may offset the gains of the lowered COPQ and can represent many operational expenses a firm incurs (Kondic et al., 2016). Activities necessary to control and improve quality slow production and increase labor and technological costs (Diamandescu, 2016). Managers can appraise the cost-effectiveness of their quality improvement programs by using the Prevention Appraisal Failure (PAF) quality-costing model (Holota et al., 2016; Kondic et al., 2016; Lim et al., 2015). Researchers found TQM does not increase profits and reduce $\mathrm{COPQ}$.

Adopting all aspects of a TQM program may not enhance a firm's financial performance. Organizational leaders utilizing all aspects of a quality improvement program may increase operational costs and decrease profits (Chorpa \& Singh, 2015; Kafetzopoulos et al., 2015). Prevention and appraisal costs may lower the profitability of the firm due to the investments business leaders make in prevention and appraisal activities necessary to sustain some quality improvement strategies (Grbac et al., 2015). Organizational members can increase profitability by adopting only the best practices of a quality improvement strategy proving to be effective within the firm and excluding ascertaining additional human resources and technological resources, as such actions by organizational members cause increased costs with low or negative returns on investments (Chorpa \& Singh, 2015). Incorporating only best-quality improvement strategies is a good practice for smalland medium-sized organizations because they often lack the capital for large-scale quality improvement strategies (Chorpa \& Singh, 2015). Utilizing all aspects of a TQM program may not enhance a firm's performance due to appraisal and prevention costs.

Adopting all aspects of TQM may not increase profits to an optimal level. Using the PAF quality costing method, managers can appraise what quality improvement practices enhance performance and find a point of pricing equilibrium (Grbac et al., 2015; Zrymiak, 2016). Many business leaders want to eschew equilibrium points where, if they spend more money on improving quality, profits will diminish (Zrymiak, 2016). Applying all of the aspects of a TQM may increase profits to a point, but if leaders spend additional capital on quality improvement beyond the equilibrium point, they may experience diminished rates of return.

Managers can use the PAF model to find a point of equilibrium wherein they have the lowest prevention, appraisal, and failure costs (Lim et al., 2015). When appraisal and prevention costs increase, failure costs should decrease, and when appraisal and prevention costs decrease, failure costs typically increase (Holota et al., 2016; Zrymiak, 2016). The reason for the phenomenon is organizational leaders will spend more capital and resources on activities and programs, which aid the finding and remedying of potential quality failures 
(Holota et al., 2016). Business managers may use the costing model to amalgamate the total costs and juxtapose them to find a price point wherein there are lowest probable total prevention, appraisal, and failure costs (Lim et al., 2015). When leaders decide to use the costing model to find a point of equilibrium, they will often abstain from utilizing some quality improvement practices, which have diminished returns on investment (Zrymiak, 2016). The diminished returns on investment often derive from increased operational costs (Holota et al., 2016; Zrymiak, 2016). Investing in quality may enhance financial performance, but in many cases, there is a point where investing in quality improvement will decrease profits due to the investment firm leaders make in the quality improvement activities.

\section{Respondents}

Researchers should search for necessary data to understand a phenomenon when conducting a qualitative case study (Dasgupta, 2015; Oye et al., 2016; Yin, 2018). One must select respondents based on the goal of their research (Dasgupta, 2015; Oye et al., 2016; Yin, 2018). The goal of this study was to identify strategies to reduce COPQ. The participants selected for this study were appropriate, as they had depth, breadth, and scope of experience with the phenomenon under investigation, which is a research approach supported by Chiarini (2015), Diamandescu and Ionita (2015), and Teixeira et al. (2015).

The participants in this study were senior managers with at least five or more years of managerial experience, including hands-on experience in developing and implementing quality improvement strategies that reduced COPQ and increased profitability.

\section{Discussion of Findings}

The overarching research question for this study is what quality improvement strategies do senior manufacturing production managers use to reduce COPQ and increase profits? The participants of this study were senior manufacturing managers with over 5 years' experience in the field. Every manager used quality improvement strategies to lower COPQ. The firm leaders institutionalized the quality improvement strategies after a major project failure, which resulted in the termination of approximately $25 \%$ of the staff. The firm also experienced an approximate loss of $\$ 500 \mathrm{~K}$. After the implementation of the strategies, the firm leaders hired $66 \%$ of those they had laid off. Analysis of the data gleaned from interviews, financial data analysis, and internal and external document reviews enabled the identification of six emergent themes, which manufacturing leaders can use to lower the COPQ to increase profitability. The six emergent themes identified were (a) continuous improvement; (b) quality assurance; (c) considering all employees agents of quality improvement; (d) communication between stakeholders; (e) holding all firm members accountable for quality; and (f) the institutionalization of training.

We associated the findings with the conceptual framework to garner a deeper understanding of what quality improvement strategies manufacturing managers can use to lower COPQ and increase profits. In this study, the quality assurance theme disputed Deming's TQM findings; however, the findings are linked to other researchers in the field of quality improvement.

\section{Theme 1: Continuous Improvement}

The most prominent theme identified following an analysis of the data is that senior managers have a goal of continuously improving. The theme aligns with the TQM conceptual framework's fifth point, to improve constantly to enhance quality and lower costs (Deming, 1986). Firm leaders can enhance their performance by incorporating a continuous process improvement program. Singh and Singh (2015) found organizational leaders can reduce costs and increase quality via continuous process improvement. Participant 2 (P2) told us the firm members use processes improvement to constantly improve and streamline the customers' needs into 
product development and product design, and they use continuous improvement, so they can continually look for potential quality problems and improve quality throughout the life of the firm. Participant 1 (P1) pointed out firm members strive to continually improve through their quality assurance practices by updating inspection checklists when individuals notice a new technique works better than the one that is in place; he mentioned the changes are not abundant but do occur incrementally. Manufacturing managers can use continuous improvement to reduce COPQ. Leaders reduce COPQ by streamlining processes and having employees search for potential quality-related problems.

\section{Lessons learned}

Lessons learned is a subtheme shared by all participants. Every participant expounded on how vital applying their lessons learned is and how they improve their quality continually through their lessons-learned documents and quality feedback circles. Managers can buttress an environment of quality via feedback circles (Deming, 1986; Juran, 1989; Schroder et al., 2015). Singh and Singh (2015) found such feedback sessions bring solutions to quality-related problems. Participant $3\left(\mathrm{P}_{3}\right)$ stated he discusses ways the firm can improve quality and processes with employees to foster continuous improvement endeavors, and he and his employees review and document internal failures and effective solutions in the lessons learned book to help ensure the failure does not occur in the future. P2 advised me lessons learned are very important to the firm, as they help to assure the employees will not repeat the same mistakes in the future. Manufacturing managers can reduce COPQ by instituting a lessons learned initiative. Leaders can reduce COPQ by discussing and documenting quality problems and by discussing and documenting countermeasures to thwart quality failures.

\section{Theme 2: Quality Assurance}

The second theme that emerged as a successful strategy to lower COPQ was quality assurance. The quality assurance theme had two subthemes: inspection and testing. All three participants explained the importance of quality assuring all products the firm members produce. P1 stated the quality assurance process saved the company and reduced COPQ by approximately 90\%. P2 told us the quality assurance process ensures completion of fabrication and the customers do not receive products that did not go through the entire quality assurance procedure. The participants of this study explained that their quality assurance and mass inspections significantly reduced their COPQ, and the firm leaders will continue to retain the activity as a valued practice, as it significantly decreased COPQ. Quality assurance was a successful strategy to reduce COPQ because it significantly reduced the number of quality failures for the firm leaders; it held firm members accountable for the firm leader's quality goals and design specifications. This theme does not align with the conceptual framework. Deming (1986) explained firm leaders should cease to rely on mass inspection to find quality failures, as it implies the firms' processes are incapable of achieving quality specifications. The findings are consistent with Plewa et al. (2016), who found investing in appraisal activities increases profits and decreases COPQ in manufacturing. The participants of this study believed the risks of internal failures are worth the investment in quality assurance. P1 explained the investment in quality assurance is sound because when they find an internal failure, it only takes a minute to rework. Quality assurance is a strategy manufacturing managers can use to lower COPQ by having employees find quality failures before the products leave the firm.

\section{Inspections}

Inspections are one of the quality assurance activities the firm members take to lower the COPQ. P3 said all products employees produce must go through quality assurance inspections, which helps hold employees accountable for their work. P2 noted inspections are vital to the quality of a product, and employees will not skip the step; if necessary, they will inform customers they will have to extend the deadline, so they do not compromise the quality of the products. Deming (1986) claimed firm leaders should cease their dependence on mass inspection; however, some inspections such as statistical testing for variance are necessary with complex and technical products. The quality assurance professionals we investigated for this study did not 
perform statistical inspections; instead, they looked at the product and compared it with the standardized work documents and examples. Inspections as a strategy to lower COPQ are consistent with other findings. Grbac et al. (2015) found inspections could reduce the likelihood of a quality failure and could cause firm leaders to invest large amounts of capital into appraisal activities. Plewa et al. (2016) asserted inspections are beneficial because employees discovered the errors in the products, developed countermeasures to the internal failures, and remedied them before they became external quality failures, decreasing costs associated with external failures, which enhanced the firm's performance. We found inspections to be a strategy to lower COPQ via the participants of this study. Inspections decrease COPQ because if a quality problem exists, employees can find the problem before it leaves the factory.

\section{Testing}

Testing is a step that a firm member can initiate to lower COPQ. P1 informed me that quality assurance professionals test every piece of equipment the firm members produce before shipping it to the customer. P2 explained testing the product via the quality assurance checklists ensures the product is of sound quality. Testing equipment is an appraisal activity and reduces the likelihood of an external quality failure (Holota et al., 2016). Testing the fabrication of products can require costly investments for business leaders (Grbac et al., 2015; Holota et al., 2016). Since the firm we investigated relies on testing all equipment to meet specifications, it is another activity that does not align with the third TQM point: cease to rely on mass inspection to find quality failures. Inspections require additional funding from executives, but the firm managers we investigated will continue to apply the practice to ensure quality problems do not occur. The mass testing of all products does not align with the conceptual framework, but it is a strategy we found to reduce COPQ and increase profits.

\section{Theme 3: Making All Employees Agents of Quality Improvement}

Making all employees agents of quality improvement is a theme shared by all participants. The theme aligns with point 12 of the TQM conceptual framework. Under the theme of making all employees agents of quality improvement, we found two subthemes when assessing the data-employee caring and employee inclusion. Deming (1986) gave several examples of how managers robbed their employees of the pride in artisanship by not instituting their suggestions to reduce COPQ and by including employees in the decision-making process only as a gesture and not implementing any countermeasures to poor quality suggested by the employees. Deming (1986)'s examples revealed a lack of caring led to higher rates of absenteeism, lower quality, and a reduction in productivity. The participants of this study announced that when they instituted employee inclusion the employees had good solutions to quality-related problems. Another byproduct of the removal of the barrier was an increase in employee caring, resulting in employees being stakeholders in the organization who were attentive about their artisanship and firm performance. Caring about the quality of their products led to better quality products.

\section{Employee inclusion}

The participants in this study attested to employee inclusion as an essential strategy to reduce COPQ. The inclusion of all employees aligns with point 12 of the TQM conceptual framework, remove barriers to worker satisfaction. When leaders involve all employees in quality improvement, their desires for a higher state of quality increase (Kanwarpreet \& Inderpreet, 2015). When business leaders make all employees responsible for the quality improvement program, the level of caring for the quality improvement strategy increases (Diamandescu, 2016; Kanwarpreet \& Inderpreet, 2015). Employee inclusion can help manufacturing managers garner high levels of buy-in to a quality improvement strategy and increase the employees' desire to produce quality products. Manufacturing managers can improve quality by including their employees in the quality improvement decision-making process.

\section{Employee caring}

Employee caring was a theme shared by all participants. The participants explained a way to reduce COPQ is 
having employees who buy-in and care about the quality improvement program. P1 suggested that to enhance quality, he needs employees to do more than come to work to collect a paycheck, and he needs his employees to care about the quality improvement program and care about the firm's performance. $\mathrm{P} 3$ said he needs the employees to be stakeholders in the quality of the products they deliver so they can circumvent any potential barriers to their quality improvement strategies. P3 charged his employees with being responsible for solutions to the quality problems, and he stated they did not let him down. P1 explained having employees who care about the firm's performance and the quality of their products is the second most crucial factor to lowering COPQ. P2 advised us the entire staff desires to produce products that exceed the customers' expectations. Charging employees with being responsible for quality and having employees who care about the quality of their products is a strategy manufacturing managers can use to lower COPQ. When employees have an interest in quality improvement, they can reduce COPQ.

\section{Theme 4: Communication Between Stakeholders}

Communication between stakeholders was an emergent theme, which manufacturing leaders can apply to lower COPQ. The theme had three subthemes, interdepartmental communication, external communication, and feedback. Communication between stakeholders aligned with the ninth point of Deming's TQM, breaking down barriers between departments. Deming (1986) noted members of all departments must work together to thwart problems in manufacturing, and firm leaders must communicate with customers to understand their needs and how they can improve the quality of their products. Enhancing communication between departments can improve quality by strengthening interdepartmental collaboration.

\section{Interdepartmental communication}

Interdepartmental communication within the firm was a strategy participants found to lower COPQ. P1 explained the firm leaders had to scrap an entire project due to poor internal communication. Following the incident, the firm leaders put mechanisms into place that fostered interdepartmental communication via the developers giving examples of the product requirements, reducing the amount of scrapping within the firm. P2 informed us of a strategy that increased the quality of their products. They implemented a formal process wherein sales representatives, engineers, and electrical drafters must communicate via meetings, emails, and matrices to develop a product to meet the needs of the customer. P2 also explained that the different department managers must formally agree on the schematics of the product design before the project may progress into another phase. Mandating and formalizing interdepartmental communication can reduce poor quality via members collaborating on what product specifications are necessary to meet customer expectations. When the development department members communicate via examples of how to accomplish a task to the employees, they can reduce the number of scrapped projects.

\section{External communication}

Having good external communication with customers is a strategy manufacturing managers can use to lower COPQ. P1 explained that firm members experience a massive loss due to poor communication with external customers. P2 mentioned the same project and explained the external customer was already at the implementation phase before they awarded the contract to his firm, which put the manufacturing firm significantly behind, and the customer demanded several changes during the firm's project execution phase. The result was the firm could not meet customer requirements due to the customer continually changing their need and specifications and the customer's unwillingness to extend the deadline for the project. P2 explained the solution was communicating with the customer transparently by explaining that if the customers make changes, firm leaders will hold the customer responsible and make them agree on extending the timeline for delivery. Communicating effectively with external stakeholders may reduce COPQ as firm managers can garner an understanding of the customer's needs and deadlines. If firm leaders also communicate transparently with the customer about their capabilities, they can prevent a situation that will not allow enough time for employees to accomplish the task. 


\section{Feedback}

Feedback is another subtheme that emerged under the communication between stakeholder's theme.

Feedback between employees and managers is a useful quality improvement strategy. Feedback between firm members and the customer can also improve the quality of products. $\mathrm{P}_{3}$ stated his employees give the feedback necessary to improve processes and enhance quality. P1 shared an experience wherein he had an employee who presented an idea to enhance the quality by offering what he believed could improve quality. The implementation of the process was expensive initially but saved the firm more than the initial investment. According to $\mathrm{P}_{3}$, external feedback with the customer is the most effective manner to assess the quality improvement strategy. P2 acknowledged that when customers give feedback about the firm's product, they gain a better understanding of their quality level and how they can improve their products and meet the customers' expectation. Manufacturing managers can reduce COPQ by finding solutions to quality problems from their employees. Following-up for feedback on product quality with the customer can provide a gauge as to the manufacturing firm's product quality.

\section{Theme 5: Holding All Firm Members Accountable for the Quality}

The fifth theme that emerged was holding all members accountable for quality. All participants shared this theme. We found three subthemes within the holding all firm members accountable for quality themedocumentation, serialization, and standardizing work. Holding all firm members accountable for quality enabled them to accomplish a high level of quality in their products and a reduction in COPQ. This theme is consistent with point seven of Deming's (1986) TQM, adopt and institute leadership. Business leaders must focus on product outcomes by developing standardized work and processes to meet design specifications (Deming, 1986). We found through this research study that the leaders of this firm institute documentation and standardized work to help their employees achieve strategic objectives.

\section{Documentation}

Documentation is the first subtheme that emerged under the holding all firm members responsible for the quality theme. P1 described a project they took on which led to multiple layoffs and almost rendered the firm insolvent due to a lack of documentation. P2 informed me about the same project and told me department managers would have a conversation about a change for the schematics in the design phase and would not correctly document the change. By the time the fabricators assembled the product, they did not incorporate the new change due to a lack of proper documentation. The lack of documentation led to some confusion, and the products failed to meet product specifications. After seeking outside consultation on their quality problems, the firm leaders instituted a new documentation methodology to improve quality and hold employees accountable. When asked about what strategies his employees use to lower COPQ, $\mathrm{P}_{3}$ stated documentation was a crucial strategy to reduce COPQ and poor documentation could be a barrier to implementing a quality improvement program. He also told us an additional documentation methodology is the application of serial numbers, and the use of serial numbers makes it easier to find who fabricated the device, quality assured it, and tested it before it left the shop. P3 mentioned the serialization also helps to conduct causal analysis if there is a quality failure. Having employees and managers document schematics and projects reduces COPQ via eliminating confusion among differing departments. Serializing is another form of documentation, which improves quality because it helps managers track who fabricates each product and it helps to find causes of quality failures.

\section{Standardizing work}

Standardizing work is a subtheme we found under holding all firm members accountable for the quality theme when we assessed the data. Before the implementation of the researched firm's quality improvement program, they were not able to meet the customer's need because they did not standardize work. After the implementation of the quality improvement program, sales, customers, engineering, and electrical drafting personnel must hold meetings to ensure the design will meet the demand of the customer and standardize the 
work via checklists managers give to the employees. P1 explained that when managers standardize work in cookie-cutter fashion, employees can more easily meet quality goals. $\mathrm{P}_{3}$ admitted a barrier to implementing quality improvement strategies is a lack of standardization, especially in his firm's sector as each project is unique and designers have to create a prototype for each project. P2 mentioned the firm members experienced a quality failure when they were under tight deadlines and completed tasks that were word of mouth and not formally scrutinized between departmental managers. After the quality failure, they instituted a mechanism wherein the production managers pass a logbook from corporate leaders explaining the specific work to the fabrication workers, which illustrates what the fabricators must accomplish to achieve project success.

\section{Theme 6: Training}

Training is an emergent theme we found to lower COPQ. The participants detailed how training increases job knowledge and the employees' ability to create products of superior quality. P1 provided an example wherein the managers would conduct training events to train new employees on how to assemble panels, and the products they produced were of the same level of quality of someone who worked for the firm for several years. P2 admitted if managers do not train subordinates on what firm leaders expect of them, the employees will lack the understanding of what good quality is and there is a higher likelihood of them producing a product of poor quality. $\mathrm{P}_{3}$ stated failing to provide guidelines and instructions to employees could be a barrier to implementing a quality improvement program. Firm leaders can reduce COPQ by training individuals on how to accomplish a task and the expectation of what the standard of quality is from organizational leaders. If firm leaders do not provide training and instructions to employees, they could impede the implementation of their quality improvement strategies.

\section{Conclusion}

While analyzing the data, we found six prominent themes. The paper modeled the naming of the themes from information gleaned during the literature review and the TQM conceptual framework. The findings for this study are that manufacturing managers can reduce COPQ and increase profits by (a) continuously improving all aspects of quality within a firm, applying lessons learned and developing a training program, (b) implementing a quality assurance program wherein quality assurance professionals inspect and test all products, (c) making all employees agents of quality and including them in quality decision-making to foster an environment wherein employees care about quality, (d) encouraging communication between all internal and external stakeholders and seeking their feedback about the quality of products and quality problems, (e) holding firm members accountable for quality by incorporating documentation and serialization practices, and (f) institutionalizing training. 


\section{References}

Ahmad, S., Pesch, M. J., \& Gulati, R. (2015). Cost of quality: Lessons from toy recalls. Journal of International Business Research, 14(2).

https://www.abacademies.org/articles/jibr vol 14 no 2 2015.pdf

Bhat, K. S., \& Rajashekhar, J. (2009). An empirical study of barriers to TQM implementation in Indian industries. TQM Journal, 21, 261-272. https://doi.org/10.1108/17542730910953031

Bloice, L., \& Burnett, S. (2016). Barriers to knowledge sharing in third sector social care: A case study. Journal of Knowledge Management, 20, 125-145. https://doi.org/10.1108/JKM-12-2014-0495

Cannon, D. F. (2002). Expanding paradigms in providing internal service. Managing Service Quality, 12, 8799. https://doi.org/10.1108/09604520210421392

Chandralal, L., \& Valenzuela, F. (2015). Memorable tourism experiences: Scale development. Contemporary Management Research, 11, 291-309. https://doi.org/10.7903/cmr.13822

Chaudary, S., Zafar, S., \& Salman, M. (2015). Does total quality management still shine? Re-examining the total quality management effect on financial performance. Total Quality Management \& Business Excellence, 26, 811-824. https://doi.org/10.1080/14783363.2014.895521

Chorpa, A. \& Singh, B. J. (2015). Unleashing a decisive approach to manage quality costs through behavioural investigation. Business Process Management Journal, 21, 1206-1223. https://doi.org/10.1108/BPMJ-07-2014-0064

Chiarini, A. (2015). Effect of ISO 9001 non-conformity process on cost of poor quality in capital-intensive sectors. The International Journal of Quality \& Reliability Management, 32, 144-153. https://doi.org/10.1108/IJQRM-03-2013-0041

Dasgupta, M. (2015). Exploring the relevance of case study research. Vision, 19, 147-160. https://doi.org/10.1177/0972262915575661

Deming, W. E. (1986). Out of the crisis. Massachusetts Institute of Technology Press.

Diamandescu, A. (2016). The significance of Total Quality Management principles in industrial organizations. Global Economic Observer. 4(2), 92-99. https://ideas.repec.org/a/ntu/ntugeo/vol4-iss2-16092.html

Drohomertetski, E., Gouvea da Costa, S. E., Pihheiro de Lima, E., \& Garbuio, P. R. (2014). Lean, Six Sigma and lean Six Sigma: An analysis based on operations strategy. International Journal of Production Research, 52. 804-824. doi:10.1080/00207543.2013.842015

Dubey, R., \& Gunasekaran, A. (2015). Exploring soft TQM dimensions and their impact on firm performance: Some exploratory empirical results. International Journal of Production Research, 53, 371-382. https://doi.org/10.1080/00207543.2014.933909

Grbac, T., Car, Z., \& Huljenic, D. (2015). A quality costs reduction model for large-scale software development. Software Quality Journal, 23, 363-390. https://doi.org/10.1007/s11219-014-9240-8

Gupta, S., \& Jain, S. K. (2015). An application of 5 S concept to organize the workplace at a scientific instruments manufacturing company. International Journal of Lean Six Sigma, 6, 73-88. https://doi.org/10.1108/IJLSS-08-2013-0047

Holota, T., Hrubec, J., Kotus, M., Holiencinova, M., \& Caposova, E. (2016). The management of quality costs analysis model. Serbian Journal of Management, 11, 119-127. https://doi.org/10.5937/sjm11-9347

Hunold, S. (2014). How to apply Six Sigma to revenue management. Journal of Revenue and Pricing Management, 13, 23-34. https://doi.org/10.1057/rpm.2013.35 
Hyvari, I. (2014). Project portfolio management in a company strategy implementation: A case study. Procedia Social and Behavioral Sciences, 119, 229-236. https://doi.org/10.1016/j.sbspro.2014.03.027

Jaca, C., Viles, Paipa-Galeano, L., Santos, J., Mateo, R. (2014). Learning 5S principles from Japanese best practitioners: Case studies of five manufacturing companies. International Journal of Production Research, 52, 4574-4586. https://doi.org/10.1080/00207543.2013.878481

Jaeger, M., \& Adair, D. (2016). Perception of TQM benefits, practices and obstacles. TQM Journal, 28, 317336. https://doi.org/10.1108/TQM-10-2014-0091

Jung, T. L. (2016). The study of total quality management and job satisfaction in land authority from north Taiwan. International Journal of Organizational Innovation, 8, 43-63. https://www.jjoionline.org/attachments/article/48/Final\%20Issue\%20Vol\%208\%20Num\%204\%20April\%202016.pdf

Juran, J. M. (1988). Juran on planning for quality. Free Press.

Juran, J. M. (1989). Juran on leadership for quality: An executive handbook. Free Press.

Kafetzopoulos, D. P., Psomas, E. L., \& Gotzamani, K. D. (2015). The impact of quality management systems on the performance of manufacturing firms. The International Journal of Quality \& Reliability Management, 32, 381. https://doi.org/10.1108/IJQRM-11-2013-0186

Kanwarpreet, S. \& Inderpreet, S. A. (2015). An evaluation of transfusion of TQM-TPM implementation in an Indian manufacturing industry. Journal of Quality in Maintenance Engineering, 21, 134-153. https://doi.org/10.1108/JQME-04-2013-0017

Kawai, N. (2015) Does downsizing really matter? Evidence from Japanese multinationals in the European manufacturing industry. The International Journal of Human Resource Management, 26, 501-519. https://doi.org/10.1080/09585192.2011.616525

Kondic, Z., Miletic, B., \& Bojanic, B. (2016). Cost of (poor) quality. In D. Mihanovic, A. Hunjet, \& Z. Primorac, Economic and social development: Book of proceedings, (pp. 469-479). https://www.esdconference.com/upload/book of proceedings/Book of Proceedings Zagreb 2016 Online.pdf

Lagrosen, Y., \& Travis, F. T. (2015). Exploring the connection between quality management and brain functioning. TQM Journal, 27, 565-575. https://doi.org/10.1108/TQM-08-2013-0093

Lawton, Eddie D., Jr., \& Ivanov, S. (2014). Satisfying internal customers: How to improve facility management at a university. International Journal of Organizational Innovation Online, 6(4), 17-21. https://www.ijoi-online.org/index.php/back-issues/39-volume-6-number-4-april-2014

Lim, C., Sherali, H., \& Glickman, T. (2015). Cost-of-quality via zero-one polynomial programming. IIE Transactions, 47, 258-273. https://doi.org/10.1080/0740817X.2014.928964

Marodin, G., \& Saurin, T. (2015) Managing barriers to lean production implementation: context matters. International Journal of Production Research, 53, 3947-3962. https://doi.org/10.1080/00207543.2014.980454

Melton, K., \& Anthony, S. (2015). When measurement becomes the mission, don't trust the measurement! The Journal for Quality and Participation, 38(1), 29-33. https://asq.org/qualityresources/articles/when-measurement-becomes-the-mission-dont-trust-themeasurement $?$ id $=55811 \mathrm{e} 5 \mathrm{a} 6$ fo14adf82111d393425aa2c

Mishra, V., \& Smyth, R. (2015). Workplace policies and training in China: Evidence from matched employeeemployer data. International Journal of Manpower, 36, 986-1011. https://doi.org/10.1108/IJM-102013-0249 
Mitreva, E., Taskov, N., Atanasoski, D., Gjorshevski, H., Sazdova, J., \& Georgieva, I. (2016). Integrating supplier satisfaction with customer satisfaction in the projection and implementation of the TQM system in Macedonian companies. International Journal of Information, Business and Management, 8(1), 25-34.

Nagi, A. \& Altarazi, S., (2017). Integration value stream map and strategic layout into DMAIC approach to improve carpeting process. Journal of Industrial Engineering and Management, 10. http://dx.doi.org/10.3926/jiem.2040

Nawelwa, J., Sichinsambwe, C., \& Mwanza, B. G. (2015). An analysis of total quality management (TQM) practices in Zambian secondary schools: A survey of Lusaka district. TQM Journal, 27, 716-731. https://doi.org/10.1108/TQM-06-2015-0080

Oye, C., Sorenson, N. O., \& Glasdam, S. (2016). Qualitative research ethics on the spot: Not only on the desktop. Nursing Ethics, 23, 455-464. https://doi.org/10.1177/0969733014567023

Pakdil, F., \& Leonard, K. M. (2014). Criteria for a lean organization: Development of a lean assessment tool. International Journal of Production Research, 52, 4587-4607. https://doi.org/10.1080/00207543.2013.879614

Parihar, S., Bhar, C., \& Kumar, R. (2015). Electrical transmission line installation projects: A Six Sigma approach for risk management. IUP Journal of Operations Management, 14(1), 54-64 https://doi.org/10.1177/0972262917700985

Patyal, V. S. \& Maddulety, K. (2015). Interrelationship between Total Quality Management and Six Sigma: A review. Global Business Review, 16, 1025-1060. https://doi.org/10.1177/0972150915597607

Plewa, M., Kaiser, G., \& Hartmann, E. (2016). Is quality still free? Empirical evidence in modern manufacturing. International Journal of Quality \& Reliability Management, 33, 1270-1286. https://doi.org/10.1108/IJQRM-11-2014-0189

Sangode, P. B. (2016). The impact of quality certifications on the quality management practices of manufacturing in Nagpur region. IUP Journal of Operations Management, 15(2), 25-33. http://www.iupindia.in/

Schroder, M., Schmitt, S., \& Schmitt, R. (2015). Design and implementation of quality control loops. TQM Journal, 27, 294-302. https://doi.org/10.1108/TQM-01-2014-0004

Singh, J., \& Singh, H. (2015). Continuous improvement philosophy: Literature review and directions. Benchmarking an International Journal, 22, 75-119. https://doi.org/10.1108/BIJ-06-2012-0038

Stanciu, I., \& Pascu, E. (2014). Quality costs. Knowledge Horizons Economics, 6(4), 39-41. https://www.orizonturi.ucdc.ro/arhiva/2014_khe_6_pdf4/stanciu.pdf

Sunder M. V. (2016). Lean Six Sigma project management-a stakeholder management perspective. TQM Journal, 28(1) 132-150. https://doi.org/10.1108/TQM-09-2014-0070

Tang, J., \& Hsu, T. (2015). A fuzzy preference relations model for evaluating key supplier relationships in TFT-LCD TV panel manufacturing industry. Management Decision, 53, 1858-1882. https://doi.org/10.1108/MD-12-2014-0691

Teixeira, H. N., Lopes, I., \& Sousa, S. (2015). Prioritizing quality problems in SMEs: A methodology. TQM Journal, 27, 2-21. https://doi.org/10.1108/TQM-12-2012-0107

Wu, S. J. (2015). The impact of quality culture on quality management practices and performance in Chinese manufacturing firms. The International Journal of Quality \& Reliability Management, 32, 799-814. https://doi.org/10.1108/IJQRM-12-2013-0199 
Yadav, V., \& Sharma, M. K. (2016). Multi-criteria supplier selection model using the analytic hierarchy process approach. Journal of Modelling in Management, 11, 326-354. https://doi.org/10.1108/JM206-2014-0052

Yin, R. K. (2018). Case study research: Design and methods (6th ed.). Sage.

Zrymiak, D. (2016). Cost of social responsibility model. The Journal for Quality and Participation, 38(4), 2326. https://secure.asq.org/perl/msg.pl?prvurl=http://rube.asq.org/qualityparticipation/2016/01/social-responsibility/cost-of-social-responsibility-model.pdf 